\title{
Biodiversity, Governance, and the Allocation of International Aid for Conservation
}

\author{
Daniel C. Miller ${ }^{1}$, Arun Agrawal ${ }^{1}$, \& J. Timmons Roberts ${ }^{2}$ \\ ${ }^{1}$ School of Natural Resources and Environment, University of Michigan, Ann Arbor, MI 48109, USA \\ ${ }^{2}$ Center for Environmental Studies, Brown University, Providence, RI 02912, USA
}

\author{
Keywords \\ Biodiversity conservation; conservation finance; \\ conservation investment; governance; foreign \\ aid; environmental aid; aid allocation.

\section{Correspondence} \\ Daniel C. Miller, 4024 Dana Building, School of \\ Natural Resources and Environment, University \\ of Michigan, Ann Arbor, MI 48109. \\ Tel: +1734-764-2550; fax: +1 734-647-5047. \\ E-mail:dcmille@umich.edu \\ Received \\ 15 Febuary 2012 \\ Accepted \\ 2 July 2012 \\ Editor \\ Dr. Robin Naidoo
}

doi: $10.1111 / j .1755-263 \times .2012 .00270 . x$

\begin{abstract}
There is little systematic knowledge about the magnitude and allocation of international funding flows to support biodiversity conservation in the developing world. Using the newly released AidData compilation, we present a comprehensive assessment of official donor assistance for biodiversity during 1980-2008. We find that biodiversity aid increased markedly in the early 1990s, but that estimates of current aid are likely overstated and donor commitments at the 1992 Rio Earth Summit have not been met. Aid has been well targeted, however, in that the allocation of biodiversity aid is positively associated with the number of threatened species in recipient countries after controlling for country size, national population, and wealth. Biodiversity aid is also positively associated with indicators of good governance. Our results provide an empirical measure of progress toward international conservation funding targets, a baseline against which future flows can be compared, and information necessary to assess the effectiveness of biodiversity aid.
\end{abstract}

\section{Introduction}

A quarter century after the word "biodiversity" was coined and nearly two decades after 192 nations met in Rio de Janeiro to develop estimates of biodiversity conservation costs, little is known about the allocation of biodiversity aid. Because many of the highest biodiversity conservation priority areas are in some of the world's poorest countries (Brooks et al. 2006), it was evident from the very beginning that effective conservation needed major financial flows (Balmford and Whitten 2003; James et al. 2001). International conservation policy, including Target 20 of the Convention on Biological Diversity's (CBD) 2011-2020 strategic plan, continues to recognize the importance of funding (CBD 2011). Two key issues thus merit analysis: amounts of flows, and how well they are targeted.

Several studies have estimated the financing necessary to reach $\mathrm{CBD}$ and other international biodiversity goals (Balmford et al. 2002; James et al. 1999, 2001; Parker et al. 2012). Although these estimates are likely low-they focus primarily on protected areas rather than the full array of strategies necessary for enduring and broad-based conservation (Chazdon et al. 2009)-they do constitute a useful starting point to understand the large-scale financial needs of conservation. Theoretical methods have also been developed to allocate conservation investments efficiently at global (Bode et al. 2008; Brooks et al. 2006; Wilson et al. 2006) and finer-grained scales (Balmford et al. 2003).

If broad-scale conservation needs and priorities are thus relatively well understood, we lack knowledge about actual expenditures on global conservation. Research has focused on specific geographic regions (Brockington and Scholfield 2010; Castro and Locker 2000), a single year (Halpern et al. 2006), individual donor types, including NGOs (Brockington and Scholfield 2010), private foundations (Zavaleta et al. 2008), the World Bank (Kareiva 
et al. 2008; Hickey and Pimm 2011), or specific conservation approaches, such as protected areas (Bruner et al. 2004; Mansourian and Dudley 2008). The most extensive study of international environmental aid to date (Hicks et al. 2008) discusses biodiversity, but only in passing and only through the year 1999.

To address this important gap in knowledge we present a comprehensive assessment of official development assistance for biodiversity from 1980-2008 using the newly released AidData compilation (AidData 2010). We also analyze whether these aid flows, which remain the largest source for conservation in the low- and middleincome countries of the developing world (Balmford and Whitten 2003; CBD 2010), have been directed to countries with higher levels of threatened species, species richness, and endemic species, and countries with better governance. This study provides a baseline against which future funding flows can be compared, a method to track progress toward biodiversity financing goals, and information necessary to assess the effectiveness of biodiversity aid. In the context of the ongoing needs assessments mandated under the CBD process, the methods and findings we present hold particular relevance for conservation policy at both national and global levels.

\section{Theoretical expectations: Allocating biodiversity aid}

Research suggests that the environmental characteristics of recipient countries are an important determinant of the allocation of environmental aid generally (Hicks et al. 2008) and biodiversity aid more specifically (Hickey and Pimm 2011). We thus expect that the relative biodiversity importance of recipient countriestheir conservation "need" - will be a positively associated with biodiversity aid allocation. Consistent with research showing that the quality of governance in aid-receiving countries is associated with the allocation of development aid (Neumayer 2003; Wright and Winters 2010), we hypothesize that biodiversity aid will correlate with indicators of "good" governance.

In addition, we expect country wealth, population, and geographic size to be associated with biodiversity aid allocation. Because biodiversity aid is part of the broader universe of development aid, which must promote "the economic development and welfare of developing countries as its main objective" (OECD 2008), we expect it to be negatively correlated with indicators of country wealth. As research on World Bank investments in protected areas suggests (Hickey and Pimm 2011), poorer countries should receive more support. Donors may also prioritize funding to such countries due to com- paratively lower conservation costs within their borders (Balmford et al. 2003). Finally, given that larger, more populous countries tend to receive more environmental aid (Connolly 1996; Hicks et al. 2008), we hypothesize that recipient country population and geographic size will be positively associated with biodiversity aid.

\section{Materials and methods}

\section{Data}

Our analysis uses data from the AidData database (2010). With nearly 1 million development project records starting from 1946, AidData is the most comprehensive source of information on international aid currently available (Tierney et al. 2011). We examine a subset of the database from 1980, when the World Conservation Strategy (IUCN et al. 1980) helped place conservation squarely on the international development agenda (Robinson 1993), to 2008, the last full year for which data were available.

To identify the universe of biodiversity-related projects we conducted a multilingual search of 120 keywords relevant to biodiversity (Table S1). This keyword list was developed deductively and inductively, from expected terms and from those found in known biodiversity projects. In addition, we translated most of the keywords into French and Spanish. The resulting query yielded 75,858 projects out of 636,962 contained in AidData 1.0 from 1980 to 2008. These projects were sorted by year, and each was coded for inclusion or exclusion depending on whether it was likely to have a positive effect on biodiversity. Projects with clear, measureable goals and criteria for success (e.g. protected area management) and those with less defined, longer-range goals (e.g. scientific research, capacity building, or policy development) were both included, as long as a connection to biodiversity conservation could be established based on project record information (Appendix S1). To establish inter-coder reliability two separate researchers associated with AidData coded each project. Coding in this manner yielded agreement for 79 percent of the projects. Projects without the same matching code were arbitrated by a senior researcher for a final decision before being included in the dataset. Using this method, we identified 9,445 biodiversity aid projects during 1980-2008. Calculations of biodiversity-related aid are based on project amounts committed by donors. Amounts reported are in constant year 2000 US\$ unless otherwise noted.

To analyze the allocation of biodiversity aid we used the total number of threatened species from three globally assessed taxa-mammals, birds, and amphibiansat the country level compiled for the IUCN Red List (IUCN 2012) as our key indicator of biodiversity need. We 
Table 1 Summary of top 10 biodiversity aid donors and aid recipient countries (in constant 2000 US\$)*

\begin{tabular}{|c|c|c|c|}
\hline \multicolumn{4}{|c|}{ Top 10 donors } \\
\hline Rank & Organization & Aid Committed & $\begin{array}{c}\text { Percent of } \\
\text { Total Biodiversity } \\
\text { Aid Committed }\end{array}$ \\
\hline 1 & World Bank (All units) & $\$ 5,798,633,226$ & $31 \%$ \\
\hline 2 & $\begin{array}{l}\text { Global Environment } \\
\text { Facility (GEF) }\end{array}$ & $\$ 5,110,000,000$ & $28 \%$ \\
\hline 3 & United States & $\$ 1,300,000,000$ & $7 \%$ \\
\hline 4 & $\begin{array}{l}\text { Inter-American } \\
\text { Development Bank } \\
\text { (IADB) }\end{array}$ & $\$ 1,120,000,000$ & $6 \%$ \\
\hline 5 & Netherlands & $\$ 783,000,000$ & $4 \%$ \\
\hline 6 & Germany & $\$ 769,000,000$ & $4 \%$ \\
\hline 7 & $\begin{array}{l}\text { European } \\
\text { Communities (EC) }\end{array}$ & $\$ 636,000,000$ & $3 \%$ \\
\hline 8 & United Kingdom & $\$ 336,000,000$ & $2 \%$ \\
\hline 9 & $\begin{array}{l}\text { Asian Development } \\
\text { Bank }\end{array}$ & $\$ 316,000,000$ & $2 \%$ \\
\hline 10 & $\begin{array}{l}\text { African Development } \\
\text { Bank }\end{array}$ & $\$ 292,600,000$ & $2 \%$ \\
\hline & Subtotal & $\$ 16,461,233,226$ & $89 \%$ \\
\hline \multicolumn{4}{|c|}{ Top 10 Country recipients } \\
\hline Rank & Country Name & Aid Received & $\begin{array}{c}\text { Percent of } \\
\text { Total Biodiversity } \\
\text { Aid Received }\end{array}$ \\
\hline 1 & India & $\$ 1,640,000,000$ & $9 \%$ \\
\hline 2 & Brazil & $\$ 1,620,000,000$ & $9 \%$ \\
\hline 3 & China & $\$ 839,000,000$ & $5 \%$ \\
\hline 4 & Mexico & $\$ 621,000,000$ & $3 \%$ \\
\hline 5 & Indonesia & $\$ 611,000,000$ & $3 \%$ \\
\hline 6 & Colombia & $\$ 526,000,000$ & $3 \%$ \\
\hline 7 & Kenya & $\$ 462,000,000$ & $2 \%$ \\
\hline 8 & Philippines & $\$ 396,000,000$ & $2 \%$ \\
\hline 9 & Madagascar & $\$ 291,000,000$ & $2 \%$ \\
\hline \multirow[t]{2}{*}{10} & Tanzania & $\$ 290,000,000$ & $2 \%$ \\
\hline & Subtotal & $\$ 7,296,000,000$ & $39 \%$ \\
\hline
\end{tabular}

* Note: Bilateral donor contributions represent biodiversity aid flowing through bilateral channels and do not include contributions to the GEF.

chose this indicator because international funding agencies, such as the Global Environment Facility have used threatened species data to develop biodiversity investment priorities (Vié et al. 2008). This indicator consists of the average number of threatened species by country for 1994 (the earliest year for which data at the country level are available), 1996, and 2004. We also used data from the EarthTrends database (WRI 2007) on species richness (the number of known species in a given country) and endemic species as alternative indicators of biodiversity need. These measures also included the total number of mammals, birds, and amphibians by country, though only for 2004 as this was the only year for which globalscale information was available.

Our measure of governance is based on the Worldwide Governance Indicators (WGI), which rank countries on six aspects of "good governance": control of corruption, voice and accountability, rule of law, government effectiveness, political stability, and regulatory quality (Kaufmann et al. 2008). Widely used by policymakers and researchers (Kaufmann et al. 2008; Langbein and Knack 2010), the WGI are highly correlated (as high as 0.94). We used principal components analysis to identify one governance component that accounts for more than $80 \%$ of the variance in the six indicators. We averaged this component for the years 2000 and 2007 to derive the governance variable for our core analysis. As a robustness check and to aid interpretation, we also developed three other indicators using principal component analysis on pairs of the six governance measures (see Tables 2 and 3 and Appendix S1).

Country geographic size is based on data on country total area in square kilometers from the CIA World Factbook (2010). We used U.S. Census Bureau (2010) data from 1990 to 2007 to develop our population variable. To correct for differences in exchange rate and cost of living among countries, our measure of country wealth uses data on gross domestic product in purchasing power parity terms (GDP-PPP) per capita from the IMF World Economic Outlook (2010) (see Appendix S1 for more information on the data used in this study).

\section{Methods}

To test whether and how strongly biodiversity aid is linked with biodiversity needs we developed both ordinary least squares (OLS) and spatial regression models. We also developed panel regression models as a robustness test and to explicitly account for the effects of time. According to our initial OLS regression model, biodiversity aid is a linear function of a suite of causal variables and a randomly distributed error term:

$$
\begin{aligned}
& \log (\text { biodiversity aid }) \\
& \quad=\beta_{0}+\beta_{1}^{*} \log (\text { threatened species }) \\
& +\beta_{2}^{*} \log (\text { area km2 }) \\
& +\beta_{3}^{*} \log (\text { population }) \beta_{4}^{*} \log (\text { GDP PPP }) \\
& +\beta_{5}^{*}(\text { governance })+\varepsilon, \varepsilon \sim N\left(0, \sigma^{2}\right)
\end{aligned}
$$

The other two OLS models we developed used the same variables but replaced threatened species with species richness and endemic species, respectively. To achieve appropriate normality, both these species-level measures were logged as well. Models included robust 


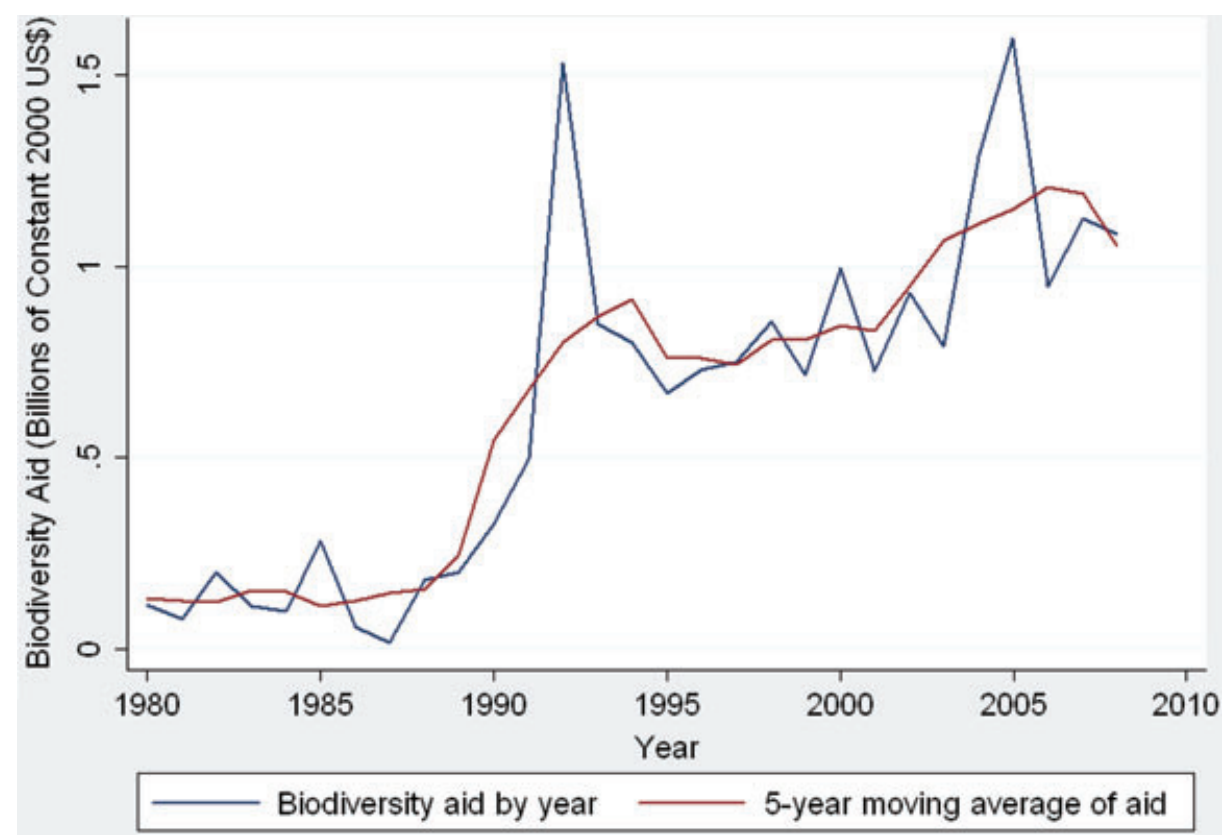

Figure 1 Temporal trends in biodiversity aid, 1980-2008.

standard errors to correct for heteroskedasticity. Descriptive statistics for the variables analyzed are in Table S2.

Given the clear jump in aid flows after 1990 and the substantially better availability of data on potential explanatory variables, our analysis covers the period 1990-2008. We summed total aid received by country during this period to derive our measure of biodiversity aid. Each independent variable includes averages of multiple years of data, beginning in 1990 or the earliest year during the study period for which data were available and concluding in 2007 to account for a potential lag in the allocation of aid based on the biological and social drivers we examine.

We sought to maximize the number of countries we analyzed using available data. The final number of countries in the analysis (137) does not include three outliers-Singapore, Iraq, and Israel-which exerted strong leverage on the regression results, preventing the requisite normality assumptions from being met. Each represents a special case: Singapore is a wealthy city-state with low biodiversity need; Iraq was at war with several key donor nations during the period under consideration; and Israel has a special aid relationship with western governments, particularly the United States.

A series of post-regression diagnostics suggest that the models meet OLS assumptions (Appendix S1). Because the Moran's I statistic (based on centroid latitude and longitude for each country) revealed significant spatial autocorrelation among the residuals in each model $(P<$
0.001 ) we estimated a spatial regression lag model where standard errors are corrected for potential spatial autocorrelation. There were no substantive differences in results from the OLS and spatial regression models (Table S3).

The panel regression models we developed include the same variables as our cross-sectional models, but incorporate separate observations by country and by year. Table S4 presents descriptive statistics on these variables. The models are estimated using OLS with robust standard errors clustered on the country unit. Models incorporated a one-year lag to account for a likely delay in social-ecological effects on aid allocation (Table 3). Results were robust using three- and five-year lags.

\section{Results}

\section{Biodiversity aid flows}

The 9,445 biodiversity-related projects in 171 countries and territories during the period 1980-2008 that are included in our analysis are funded by 52 bi- and multi-lateral aid agencies. Together, they represent US\$ 18.55 billion in biodiversity aid. Like environmental aid generally (Hicks et al. 2008), biodiversity aid exhibits substantial inter-annual fluctuations; a 5-year moving average reveals an overall upward trend, with two periods of increase followed by stagnation (Figure 1). Biodiversity funding averaged about $\$ 200$ million annually in the 1980s, but spiked to more than $\$ 1.5$ billion 


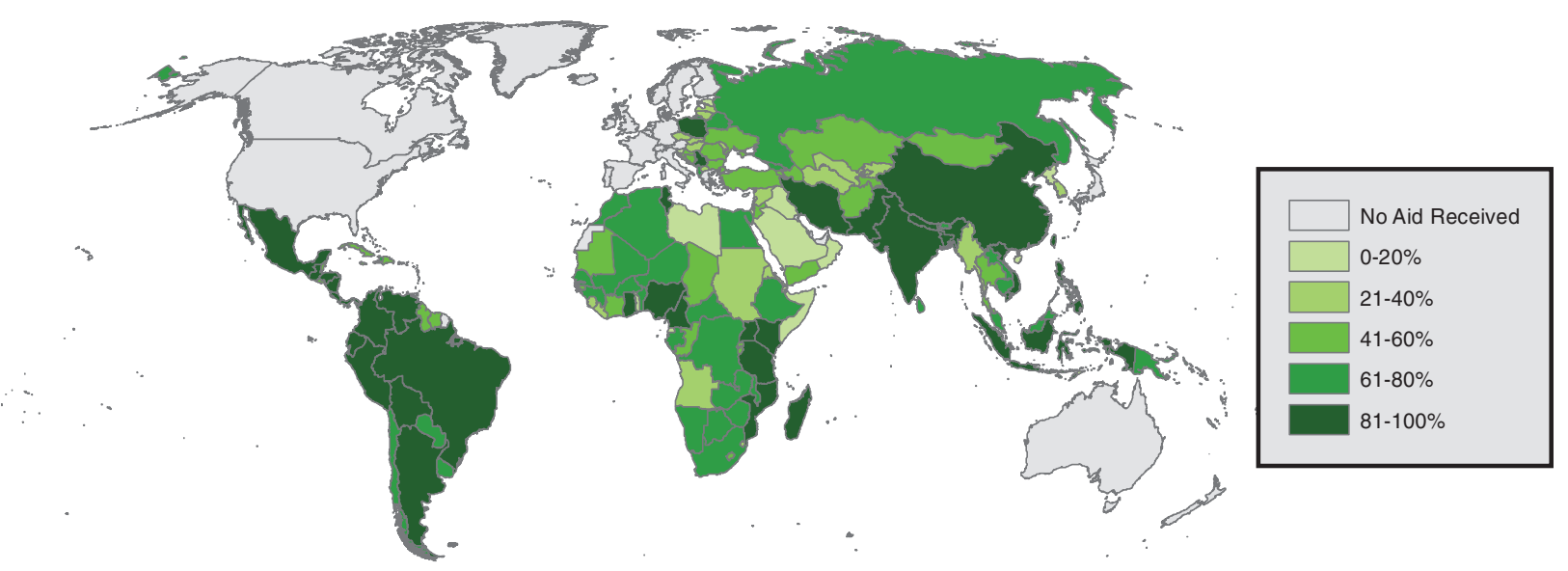

Figure 2 Geographic distribution of biodiversity aid allocation to recipient countries. Recipient countries are divided into quintiles based on total aid received during 1980-2008. The lightest shade indicates bottom $20 \%$ of biodiversity-related aid receiving countries and the darkest shade indicates top $20 \%$ of aid recipients. Countries in grey received no biodiversity aid during the study period.

in 1992, and averaged approximately $\$ 800$ million annually over the next decade. Growth during the post-1990 period is traceable to the creation of the Global Environment Facility (GEF) in 1991 and pledges at the 1992 Rio Summit. Since 2002, biodiversity aid has shifted to a new average of $\$ 1.1$ billion annually, a 4.5 fold increase from the 1980s.

Despite the upward trend, annual flows remain well short of Rio commitments. Under Agenda 21, industrialized countries promised nearly $\$ 18$ billion annually for global environmental issues through grants and low or no-interest concessional loans, with about $\$ 2$ billion of this designated for biodiversity protection (Hicks et al. 2008). Donor nations have not met their commitment in any year since making this promise in 1992. Total funding ( $\$ 18.55$ billion) is $58 \%$ of the Rio promise ( $\$ 32$ billion in constant 2000 US\$).

Our biodiversity aid flow estimates are less than those reported in earlier studies that use Organization for Economic Co-operation and Development (OECD) data (see Discussion and Appendix S1). For example, an influential assessment of progress toward the CBD 2010 target (Butchart et al. 2010) estimated the level of biodiversity aid at US\$3.13 billion in 2007. Using AidData, we find that total biodiversity aid in 2007 (current US\$1.35 billion) is just $43 \%$ of that amount.

During the period 1980-2008, the top 10 donors account for nearly $90 \%$ of total biodiversity aid flows (Table 1). The top two donors, the World Bank and the Global Environment Facility are far and away the largest contributors, providing approximately $60 \%$ of all biodiversity aid (nearly $\$ 11$ billion). Together, the top 10 bilateral donors provided more than $\$ 5$ billion $(27 \%$ of the total), with the United States the largest bilateral donor.
Of the 171 countries and territories that received biodiversity aid during the study period ( Figure 2), the top 10 recipient countries account for nearly $40 \%$ of the total receipts (Table 1$)$. In addition, $\$ 3.4$ billion (17\%) of the aid is not traceable to a specific country or territory; it is instead reported as "global," "unallocated," or committed to a region (e.g. "Africa"). These terms designate aid channeled to more than one country (as for transboundary conservation efforts), or for strengthening international treaties and regimes related to biodiversity conservation.

\section{Targeting biodiversity aid}

We find that higher levels of biodiversity aid are significantly associated with higher levels of biodiversity need after controlling for national population, land area, and poverty (Tables $2 \& 3$ ). On average, a 10\% difference in the number of threatened species between countries is associated with a $10 \%$ difference in the allocation of biodiversity aid; a 10\% higher level of species richness is associated with a 14\% higher level of biodiversity aid. Endemic species has a weaker relationship: a $10 \%$ increase in this measure is associated with a $4 \%$ increase in aid.

Better governance scores are positively and strongly associated with the allocation of biodiversity aid. The effect of governance on aid allocation is strongest in the panel models: a one-unit increase in our main governance indicator is associated with about a $45 \%$ increase in biodiversity aid for models1-3. Results are robust to alternative governance indicators, with the indicator based on government effectiveness and regulatory quality especially strongly associated with aid allocation (a one unit increase in this measure is associated with an $88 \%$ increase in biodiversity aid). 
Table 2 Results for spatial regression lag models of aid allocation (1-6) in which biodiversity aid (in constant 2000 US\$) is the dependent variable

\begin{tabular}{|c|c|c|c|c|c|c|}
\hline Variable & (1) & (2) & (3) & (4) & (5) & (6) \\
\hline \multirow[t]{2}{*}{ Threatened species } & $1.011^{* * *}$ & - & - & $1.005^{* * *}$ & $0.999^{* * *}$ & $0.972^{* * *}$ \\
\hline & $(0.231)$ & - & - & $(0.233)$ & $(0.232)$ & $(0.228)$ \\
\hline \multirow[t]{2}{*}{ Species richness } & - & $1.384^{* * * *}$ & - & - & - & - \\
\hline & - & $(0.227)$ & - & - & - & - \\
\hline \multirow[t]{2}{*}{ Endemic species } & - & - & $0.432^{* * *}$ & - & - & - \\
\hline & - & - & $(0.096)$ & - & - & - \\
\hline \multirow[t]{2}{*}{ Governance1 } & $0.188^{*}$ & $0.139^{+}$ & $0.174^{*}$ & - & - & - \\
\hline & $(0.0812)$ & $(0.078)$ & $(0.0817)$ & - & - & - \\
\hline \multirow[t]{2}{*}{ Governance2 } & - & - & - & 0.116 & - & - \\
\hline & - & - & - & $(0.114)$ & - & - \\
\hline \multirow[t]{2}{*}{ Governance3 } & - & - & - & - & $0.318^{*}$ & - \\
\hline & - & - & - & - & (0.129) & - \\
\hline \multirow[t]{2}{*}{ Governance4 } & - & - & - & - & - & $0.397^{* *}$ \\
\hline & - & - & - & - & - & $(0.127)$ \\
\hline \multirow{2}{*}{ GDP PPP per capita } & $-0.373^{*}$ & $-0.275^{+}$ & $-0.439^{* *}$ & $-0.240^{+}$ & $-0.406^{*}$ & $-0.394^{* *}$ \\
\hline & $(0.155)$ & $(0.145)$ & (0.164) & $(0.145)$ & $(0.158)$ & (0.152) \\
\hline \multirow[t]{2}{*}{ Population size } & $0.249^{*}$ & $0.393^{* * *}$ & $0.347^{* * *}$ & $0.245^{*}$ & $0.214^{+}$ & $0.304^{* *}$ \\
\hline & $(0.113)$ & $(0.093)$ & $(0.105)$ & $(0.113)$ & $(0.111)$ & $(0.117)$ \\
\hline \multirow[t]{2}{*}{ Country area } & -0.041 & -0.166 & 0.11 & -0.063 & -0.031 & -0.037 \\
\hline & (0.098) & $(0.103)$ & $(0.097)$ & $(0.102)$ & $(0.097)$ & $(0.096)$ \\
\hline \multirow[t]{2}{*}{ Constant } & $13.46^{* * *}$ & $7.145^{* * *}$ & $12.43^{* * *}$ & $12.73^{* * *}$ & $14.22^{* * *}$ & $12.85^{* * *}$ \\
\hline & $(1.908)$ & $(1.724)$ & $(1.892)$ & $(1.867)$ & $(1.961)$ & $(1.929)$ \\
\hline Variance ratio & 0.46 & 0.50 & 0.47 & 0.45 & 0.47 & 0.48 \\
\hline Root MSE & 1.34 & 1.29 & 1.34 & 1.36 & 1.33 & 1.32 \\
\hline$\chi 2$ (Wald Test) & 0.034 & $3.274^{+}$ & 0.427 & 0.029 & 0.018 & 0.024 \\
\hline Lagrange multiplier & 0.047 & $4.350^{*}$ & 0.617 & 0.037 & 0.025 & 0.034 \\
\hline
\end{tabular}

$N=137$. All variables (natural) log transformed, except governance variables, which were not transformed. Governance $1=$ one component of the six WGI indicators; governance 2 = one component of rule of law and control of corruption; governance $3=$ one component of government effectiveness and regulatory quality; and governance $4=$ one component of voice and accountability and political stability. Robust standard errors in parentheses; ${ }^{* * *} P<0.001, * * P<0.01, * P<0.05,+P<0.10$.

The geographic size of a country does not generally correlate with biodiversity aid. Population is a significant and positive predictor of aid in all cross-sectional models, but in none of the panel models. Per capita GDP-PPP is negatively correlated with biodiversity aid in all models, though its effect is minimal (a roughly $4 \%$ increase in biodiversity aid as this indicator increases by $10 \%$ in the cross-section models and a negligible effect in the panel models).

\section{Discussion}

This study advances understanding of international financing for biodiversity conservation in three ways. First, it presents an overall portrait of global flows of biodiversity aid over the past three decades. Second, it develops a method to independently identify biodiversityrelated aid and thereby track progress toward the goal of the CBD 2011-2020 strategic plan to "increase substantially" financing for biodiversity (CBD 2011). Finally, it evaluates key social and ecological factors associated with inter-country variations in international biodiversity aid allocation.

Although biodiversity-related aid has increased substantially since 1980, funding falls well short of amounts promised in Rio by wealthy nations and is significantly less than reported in previous studies. Relative to estimates of conservation costs in the developing world (Balmford et al. 2003; James et al. 1999), existing levels of biodiversity aid are likely insufficient. Earlier estimates of aid flows may have been overstated because the existing "state of the art" tracking of official biodiversity assistance is based on donor-reported numbers through the OECD Creditor Reporting System (CRS) and donors may have an incentive to show significant financial support toward their Rio commitments (Michaelowa and Michaelowa 2011). Our method of calculating biodiversity-related aid addresses this shortcoming through independent, consistent categorization across donors and across years. It also includes a wider universe than OECD-CRS donors.

While we identify substantial shortfalls in aid, we find that the aid that has been allocated appears to be reaching 
Table 3 Results for panel regression models of aid allocation (1-6) in which biodiversity aid (in constant 2000 US\$) is the dependent variable

\begin{tabular}{|c|c|c|c|c|c|c|}
\hline Variable & (1) & (2) & (3) & (4) & (5) & (6) \\
\hline Threatened & $1.128 * * *$ & - & - & $1.152^{* * *}$ & $1.061^{* * *}$ & $1.135^{* * *}$ \\
\hline species & $(0.194)$ & - & - & $(0.201)$ & (0.193) & (0.195) \\
\hline Species & - & $1.468^{* * *}$ & - & - & - & - \\
\hline richness & - & $(0.285)$ & - & - & - & - \\
\hline Endemic & - & - & $0.419^{* * *}$ & - & - & - \\
\hline species & - & - & $(0.093)$ & - & - & - \\
\hline \multirow[t]{2}{*}{ Governance1 } & $0.373^{* * *}$ & $0.373^{* *}$ & $0.350^{* *}$ & - & - & - \\
\hline & $(0.109)$ & $(0.111)$ & $(0.11)$ & - & - & - \\
\hline \multirow[t]{2}{*}{ Governance2 } & - & - & - & $0.365^{*}$ & - & - \\
\hline & - & - & - & (0.159) & - & - \\
\hline \multirow[t]{2}{*}{ Governance3 } & - & - & - & - & $0.630^{* * *}$ & - \\
\hline & - & - & - & - & $(0.155)$ & - \\
\hline \multirow[t]{2}{*}{ Governance4 } & - & - & - & - & - & $0.557^{* * *}$ \\
\hline & - & - & - & - & - & $(0.155)$ \\
\hline GDP PPP & $-0.000^{* *}$ & $-0.000^{* *}$ & $-0.000^{* * *}$ & $-0.000^{* *}$ & $-0.000^{* * *}$ & $-0.000^{* * *}$ \\
\hline \multirow[t]{2}{*}{ Per Capita } & $(0.000)$ & $(0.000)$ & $0.000^{* * *}$ & $(0.000)$ & $0.000^{* * *}$ & $0.000^{* * *}$ \\
\hline & & & $(0.000)$ & $(0.000)$ & $(0.000)$ & $(0.000)$ \\
\hline Population & -0.000 & 0.000 & -0.000 & -0.000 & -0.000 & -0.000 \\
\hline Size & $(0.000)$ & $(0.000)$ & $(0.000)$ & $(0.000)$ & $(0.000)$ & $(0.000)$ \\
\hline Country & 0.064 & 0.083 & $0.239^{*}$ & 0.033 & 0.049 & 0.081 \\
\hline Area & $(0.117)$ & $(0.111)$ & (0.109) & $(0.116)$ & $(0.11)$ & $(0.117)$ \\
\hline \multirow[t]{2}{*}{ Year } & $0.072^{*}$ & $0.081^{*}$ & $0.074^{*}$ & $0.055+$ & $0.078^{*}$ & $0.060+$ \\
\hline & (0.033) & $(0.033)$ & $(0.032)$ & $(0.033)$ & (0.033) & $(0.031)$ \\
\hline \multirow[t]{2}{*}{ Constant } & $-134.9^{*}$ & $-157.8^{*}$ & $-137.2^{*}$ & -99.43 & $-144.7^{*}$ & -111.2 \\
\hline & (65.73) & (66.81) & (64.48) & $(66.27)$ & (65.39) & $(62.41)$ \\
\hline Observations & 218 & 218 & 201 & 218 & 218 & 218 \\
\hline$R 2$ & 0.321 & 0.303 & 0.309 & 0.28 & 0.34 & 0.288 \\
\hline
\end{tabular}

One-year lag model. All variables (natural) log transformed, except governance variables, which were not transformed. Governance $1=0$ one component of the six WGI indicators; governance 2 = one component of rule of law and control of corruption; governance $3=$ one component of government effectiveness and regulatory quality; and governance $4=$ one component of voice and accountability and political stability. Robust standard errors clustered on country in parentheses; ${ }^{* * *} P<0.001,{ }^{* *} P<0.01,{ }^{*} P<0.05,+P<0.10$.

countries with greater conservation needs and countries that are likely to use funds more transparently and accountably. This finding contrasts with other studies that report a mismatch between conservation priorities and expenditures (e.g. Halpern et al. 2006). Aid flows are positively and strongly associated with national numbers of threatened species, species richness, and endemic species. Our governance findings are similarly robust. Perceptions of the regulatory quality and effectiveness of governments appear to be particularly important determinants in the targeting of biodiversity aid.

Our findings on the relationship between population and biodiversity aid are mixed. The positive, but weak association between these two variables in our crosssectional models may be because countries that have high biodiversity value tend to have larger populations ((Brooks et al. 2006), Spearman's $\left(r_{\mathrm{s}}\right)$ correlation between population and threatened species: $=0.72$, species richness $=0.57$, and endemic species $=0.39 ; P<0.001)$. The association may also show that donors target aid to coun- tries with larger populations because biodiversity is perceived to be under greater threat in such places (McKee et al. 2004). However, population is not significant in the panel models, which may suggest that donor decisionmaking is more sensitive to perceptions of changes in governance than to changes in population.

The negative correlation we find between national income (GDP-PPP) per capita and biodiversity aid may reflect donor prioritization of support to biodiversity projects in poorer nations where costs are lower. Though the magnitude of the effect is relatively weak, this result accords with findings from recent studies of biodiversity aid allocation (Hicks et al. 2008; Hickey and Pimm 2011).

Consistent with studies underlining the importance of both ecological and social factors in conservation priority-setting (Bode et al. 2008; O'Connor et al. 2003), our results support the conclusion that aid agencies find synergies between recipient country conservation need and "good governance" in their biodiversity-related investments. To shed light on this apparent synergy 
we tested statistical models that included an interaction term, but did not find conclusive evidence for interactive effects of governance and biodiversity indicators on biodiversity aid. Additional process- or case-based research is required to better understand the relationship between biodiversity need and governance in shaping biodiversity aid allocation.

Although our results indicate that donors want conservation investments to be used more effectively, it is not clear whether that has been the case. Understanding where biodiversity aid has been directed and why may help answer whether and under what conditions aid is effective (Tierney et al. 2011). Because the impacts of biodiversity aid are likely shaped by many countryspecific factors, inferring the pathways through which aid affects conservation outcomes will require finer-grained data and more sophisticated analyses. Systematic evaluation of biodiversity aid effectiveness remains a research frontier, one that assumes particular importance as the international community seeks to take the steps necessary to reach shared biodiversity conservation targets.

\section{Acknowledgements}

We are grateful to Christian Peratsakis, Nicole Buchholz, Michael Weissberger, and the broader AidData team for their assistance coding the aid data. We thank Michael Hoffman for help with the threatened species data, Nate Schafrick for creating the map, Giselle Kolenic and Heidi Reichert for statistical assistance, and three anonymous reviewers for their comments. Support from the MacArthur Foundation through the Advancing Conservation in a Social Context research initiative is gratefully acknowledged.

\section{Supporting Information}

Additional Supporting Information may be found in the online version of this article:

Appendix S1: Materials and Methods

Table S1: English language keywords used to identify biodiversity-related aid

Table S2: Descriptive Statistics for Cross-Section Models

Table S3: OLS and Spatial Regression Results

Table S4: Descriptive Statistics for Panel Models

Please note: Wiley-Blackwell is not responsible for the content or functionality of any supporting materials supplied by the authors. Any queries (other than missing material) should be directed to the corresponding author for the article.

\section{References}

AidData. (2010). http://www.aiddata.org.

Balmford A., Bruner A., Cooper P. et al. (2002). Economic Reasons for Conserving Wild Nature. Science 297, 950-953.

Balmford A., Gaston K.J., Blyth S., James A. \& Kapos V. (2003). Global variation in terrestrial conservation costs, conservation benefits, and unmet conservation needs. Proc. Nat. Acad. Sci. USA 00, 1046-1050.

Balmford A. \& Whitten T. (2003). Who should pay for tropical conservation, and how could the costs be met? Oryx 37, 238-250.

Bode M., Wilson K.A., Brooks T.M. et al. (2008). Cost-effective global conservation spending is robust to taxonomic group. Proc. Nat. Acad. Sci. USA 105, 6498-6501.

Brockington D. \& Scholfield K. (2010). Expenditure by conservation nongovernmental organizations in sub-Saharan Africa. Conserv. Lett. 3, 106-113.

Brooks T.M., Mittermeier R.A., da Fonseca G.A.B. et al. (2006). Global biodiversity conservation priorities. Science 313, 58-61.

Bruner A.G., Gullison R.E. \& Balmford A. (2004). Financial costs and shortfalls of managing and expanding protected-area systems in developing countries. BioScience 54, 1119-1126.

Butchart S.H.M., Walpole M., Collen B. et al. (2010). Global biodiversity: indicators of recent declines. Science $\mathbf{3 2 8}$, 1164-1168.

Castro G. \& Locker I. (2000). Mapping conservation investments: an assessment of biodiversity funding in Latin America and the Caribbean. Biodiversity Support Program, Washington, DC.

Central Intelligence Agency (CIA). (2010). The World Factbook. https://http://www.cia.gov/library/publications/ the-world-factbook/.

Chazdon R.L., Harvey C.A., Komar O. et al. (2009). Beyond reserves: a research agenda for conserving biodiversity in human-modified tropical landscapes. Biotropica 41, 142-153.

Connolly B. (1996). Increments for the Earth: the politics of environmental aid. Pages 327-365 in R.O. Keohane \& M.A. Levy editors. Institutions for environmental aid: pitfalls and promise. The MIT Press, Cambridge, MA.

Convention on Biological Diversity (CBD). (2010). Global Monitoring Report 2010: Innovative Financing for Biodiversity. Available online: http://www.cbd.int/ financial/doc/global-monitoring-report-2010-en.pdf.

Convention on Biological Diversity (CBD). (2011). http://www.cbd.int/financial/.

Halpern B.S., Pyke C.R., Fox H.E., Haney J.C., Schlaepfer M., A .\& Zaradic P. (2006). Gaps and Mismatches between global conservation priorities and spending. Conserv. Biol. 20, 56-64.

Hickey V. \& Pimm S.L. (2011). How the World Bank funds protected areas. Conserv. Lett. 4, 269-277. 
Hicks R.L., Parks B.C., Roberts J.T. \& Tierney M.J. (2008). Greening Aid? understanding environmental assistance to developing countries. Oxford University Press, Oxford.

International Monetary Fund (IMF). (2010). World economic outlook database. International Monetary Fund, Washington, DC.

IUCN. (2012). The IUCN Red List of Threatened Species. http://www.iucnredlist.org.

IUCN, UNEP, WWF. (1980). World conservation strategy: living resource conservation for sustainable development. IUCN - International Union for Conservation of Nature and Natural Resources Gland, Switzerland.

James A.N., Gaston K.J. \& Balmford A. (1999). Balancing the Earth's accounts. Nature 401, 323-324.

James A.N., Gaston K.J. \& Balmford A. (2001). Can we afford to conserve biodiversity? BioScience 51, 43-52.

Kareiva P., Chang A. \& Marvier M. (2008). Development and conservation goals in world bank projects. Science 321 , 1638-1639.

Kaufmann D., Kraay A. \& Matsruzzi M. (2008). Governance matters VII: aggregate and individual governance indicators, 1996-2007. World Bank, Washington, DC.

Langbein L. \& Knack S. (2010). The worldwide governance indicators: six, one, or none? J. Dev. Stud. 46, 350-370.

Mansourian S. \& Dudley N. (2008). Public funds to protected areas. WWF International, Gland.

McKee J.K., Sciulli P.W., Fooce C.D. \& Waite T.A. (2004). Forecasting global biodiversity threats associated with human population growth. Biol. Conserv. 115, 161-164.

Michaelowa A., Michaelowa K. (2011). Coding Error or Statistical Embellishment? The Political Economy of Reporting Climate Aid. World Dev. 39, 2010-2020.
Neumayer E. (2003). The pattern of aid giving: the impact of good governance on development assistance. Routledge, London.

O'Connor C., Marvier M. \& Kareiva P. (2003). Biological vs. social, economic and political priority-setting in conservation. Ecol. Lett. 6, 706-711.

Organization for Economic Co-operation and Development (OECD). (2008). Is it ODA?, http://www.oecd.org/dac/ stats/methodology.

Parker C., Cranford M., Oakes N. \& Leggett M., editors. (2012). The Little Biodiversity Finance Book. Global Canopy Programme, Oxford, UK.

Robinson J.G. (1993). The limits to caring: sustainable living and the loss of biodiversity. Conserv. Biol. 7(1), 20-28.

Tierney M.J., Nielson D.L., Hawkins D.G. et al. (2011). More dollars than sense: refining our knowledge of development finance using AidData. World Dev. 39, 1891-1906.

U.S. Census Bureau. (2010). International Data Base. U.S. Census Bureau, Washington, DC.

Vié J.-C., Hilton-Taylor C., Pollock C. et al. (2008). The IUCN red list: a key conservation tool. In J.-C. Vié, C. Hilton-Taylor, S.N. Stuart editors. The 2008 Review of The IUCN Red List of Threatened Species. IUCN, Gland, Switzerland.

Wilson K.A., McBride M.F., Bode M. \& Possingham H.P. (2006). Prioritizing global conservation efforts. Nature 440, 337-340.

World Resources Institute. (2007). EarthTrends: environmental information. World Resources Institute, Washington, DC.

Wright J. \& Winters M. (2010). The Politics of Effective Foreign Aid. Ann. Rev. Pol. Sci. 13, 61-80.

Zavaleta E., Miller D.C., Salafsky N. et al. (2008). Enhancing the engagement of U.S. private foundations with conservation science. Conserv. Biol. 22, 1477-1484. 